\title{
Congenital Cystic Hygroma
}

National Cancer Institute

\section{Source}

National Cancer Institute. Congenital Cystic Hygroma. NCI Thesaurus. Code C116899.

A congenital lymphatic malformation usually arising from the neck and characterized by cystic dilation of the lymphatic vessels. 